\title{
Review
}

\section{Genetics of stroke}

\author{
Jin-min GUO, Ai-jun LIU, Ding-feng SU* \\ Department of Pharmacology, School of Pharmacy, Second Military Medical University, Shanghai 200433, China
}

\begin{abstract}
Stroke is the second most common cause of death and the most common cause of disability in developed countries. Stroke is a multifactorial disease caused by a combination of environmental and genetic factors. Numerous epidemiologic studies have documented a significant genetic component in the occurrence of strokes. Genes encoding products involved in lipid metabolism, thrombosis, and inflammation are believed to be potential genetic factors for stroke. Although a large group of candidate genes have been studied, most of the epidemiological results are conflicting. Studies of stroke as a monogenic disease have made huge progress, and animal models serve as an indispensable tool to dissect the complex genetics of stroke. In the present review, we provide insight into the role of in vivo stroke models for the study of stroke genetics.
\end{abstract}

Keywords: genetics; stroke; ischemic stroke; hemorrhagic stroke

Acta Pharmacologica Sinica (2010) 31: 1055-1064; doi: 10.1038/aps.2010.141; published online 23 Aug 2010

\section{Introduction}

Stroke is the second most common cause of death and disability in developed countries ${ }^{[1]}$. Ischemic stroke is the most common, with an estimated incidence of approximately $80 \%{ }^{[2]}$. A less common subtype of stroke is hemorrhagic stroke, which occurs due to subarachnoid hemorrhage (SAH) and/or intracerebral hemorrhage (ICH). In general, stroke is a heterogeneous, multi-factorial disease caused by the combination of certain risk factors and genetic factors ${ }^{[3]}$. Conventional risk factors, including hypertension, cigarette smoking, diabetes, atrial fibrillation and obesity, account for much of the risk of stroke ${ }^{[3]}$. Unfortunately, these risk factors explain only approximately $60 \%$ of cases ${ }^{[4]}$. There may be other important factors, including genetic factors, that have not yet been identified. Genetic background, suggested by various studies in families, twins and animal models, might contribute to a predisposition to stroke ${ }^{[5]}$.

There are two major approaches to find genes related to stroke: the candidate gene approach and the genome-wide approach $(\mathrm{GWA})^{[6]}$. The former has become more popular recently. Genes encoding proteins involved in lipid metabolism, thrombosis, atherosclerosis and others are thought to be potential genetic factors for stroke. The GWA entails genotyping several hundreds of thousands of genetic variants and is a powerful tool to identify new susceptibility genes and provide new insights into the pathogenesis and prevention of stroke.

\footnotetext{
* To whom correspondence should be addressed. E-mail dfsu2008@gmail.com

Received 2010-05-22 Accepted 2010-07-20
}

However, if no biologically plausible gene or no annotated genes can be identified in the regions of interest, the interpretation of GWAs remains obscure ${ }^{[7]}$.

In this review, we summarize epidemiologic evidence for a genetic component to the occurrence of ischemic and hemorrhagic stroke. The monogenic and multi-factorial aspect, respectively, are discussed in the two types of stroke. Animal models and the potential clinical application of genetics in stroke treatment are also addressed in this manuscript.

\section{Ischemic stroke}

Normally, ischemic stroke is divided into small-vessel, largevessel and cardio-embolic subtypes. Evidence shows that genetic factors are more important in small- and large-vessel stroke than in cardio-embolic stroke ${ }^{[8,9]}$. Some intermediate phenotypes also exhibit high heritability, such as carotid intima-medial wall thickness (IMT) and white-matter lesions $(\mathrm{WML})^{[3]}$. Single-gene and multi-factorial stroke are both included.

\section{Single-gene disorders with ischemic stroke}

Cerebral autosomal dominant arteriopathy with subcortical infarcts and leukoencephalopathy (CADASIL) is an adultonset, inherited autosomal dominant disease characterized by recurrent strokes and progressive dementia, with or without migraine-like headaches, seizures, and pseudobulbar palsy ${ }^{[10]}$. Notch3 mutations, located on chromosome 19p12, have been identified as a genetic cause of CADASIL ${ }^{[11]}$. Notch3 is a highly conserved trans-membrane receptor of the Notch 
family that is involved in signaling events that control cell fate decisions during embryonic development ${ }^{[12]}$. Most of the mutations are missense mutations and result in an odd number of cysteine residues within one of the epidermal growth factor (EGF)-like domains; these mutations may cause ineffective signaling and/or accumulation of Notch3 molecules at extra-cellular spaces, which leads to toxicity at tissues expressing Notch ${ }^{[13]}$. Notch3 expression is restricted to smooth muscle cells (SMCs) $)^{[13]}$, and thus, progressive degeneration of SMCs appears to be important in the pathogenesis of CADASIL. The ultrastructural study of SMCs demonstrated deposits of granular osmiophilic material (GOM) of unknown nature near the basement membrane of SMCs ${ }^{[14]}$, which seems to be a degeneration product of SMCs. Hundreds of families with Notch3 mutations have been described, with the majority being of European origin ${ }^{[10]}$. Relatively fewer mutation sites have been found in Asian populations. CADASIL might have been overlooked in Asia because of the higher baseline occurrence of vascular dementia ${ }^{[15]}$. Racial differences in the contribution of Notch3 mutations may also be a factor. Heterozygous mutations in Notch 3 have been demonstrated in more than $90 \%$ of families with CADASIL in some Caucasian studies ${ }^{[13]}$. However, in Japanese studies ${ }^{[15]}$, the mutations were found in less than $25 \%$ of CADASIL families, and in one large family, investigators did not see any significant linkage to marker genes on chromosome $19^{[15]}$. These results suggest the existence of other risk genes in Asian populations. Notch3 is a receptor for a ligand, and the ligands are thought to be Delta and Jagged, as in other Notch molecules. Therefore, mutations in ligand genes may cause a similar condition.

Fabry disease is an X-linked lysosomal storage disorder caused by deficiency of $\alpha$-galactosidase A (GLA), which results in the storage of globotriaosylceramide (Gb3) in various organs, particularly in the myocardium, renal epithelium, skin, eye, and vasculature ${ }^{[16]}$. Fabry's disease is surprisingly common in young stroke patients ${ }^{[16]}$. Most patients carry missense or nonsense mutations in the coding region of GLA. Stroke in patients with Fabry disease occurs typically by the third or fourth decade of life and manifests as both large-artery disease and small-vessel disease, with a preference for the posterior circulation ${ }^{[3]}$. Most strokes appear to be related to in situ thrombosis of a small-caliber blood vessel with Gb3 deposits. In Fabry disease, however, many heterozygous women present with the full spectrum of disease manifestations but with a later onset of symptoms, a slower rate of progression, and a higher phenotypic variability than men $^{[3]}$. Affected males are diagnosed readily by determining the level of GLA activity in plasma or peripheral leukocytes. Affected females have normal to very low levels of GLA activity, and therefore, genetic diagnosis in females is essential. The Multiplex Ligationdependent Probe Amplification (MLPA), a recent technique that can easily detect rearrangements, would be well suited for routine detection of deletions and duplications ${ }^{[17]}$ and would therefore improve GLA mutational screening.

Sickle-cell disease (SCD) is an autosomal recessive disorder caused by a mutation in hemoglobin and is referred to as hemoglobin $\mathrm{S}(\mathrm{HbS})^{[3]}$. The mutation is a valine to glutamic acid substitution in the 6th amino acid position in the $\beta$-globin chain. The geographic origins of HbS lie in regions of the world with endemic malaria, where the heterozygote condition confers relative resistance to malaria and thus confers a survival advantage. Generation of $\mathrm{HbS}$ is a monogenic event, however, the phenotype of SCD is multi-genic ${ }^{[18]}$. Other genes not linked to the $\beta$-globin locus participate in relevant pathological events that are controlled by many genes ${ }^{[18]}$. For example, a $158 \mathrm{C} / \mathrm{T}$ mutation upstream of the gene that enhances fetal hemoglobin $(\mathrm{HbF})$ expression has an inhibitory effect on the polymerization of HbS. Additionally, it has been found that under steady state conditions, SCD patients show evidence of ongoing inflammation and exhibit polymorphisms in the vascular cell adhesion molecule (VCAM), P-selectin and IL-4 receptor gene, which is also associated with stroke risk in $\mathrm{SCD}^{[19]}$. SCD is the most common cause of stroke in children. A critical component in the pathogenesis of SCD is that sickled red blood cells tend to adhere to the endothelium, thus favoring thrombus formation and vascular occlusion ${ }^{[3]}$. The Stroke Prevention in Sickle Cell Disease (STOP) trial ${ }^{[20]}$ showed that long-term transfusion therapy dramatically reduces the risk of a first stroke in high-risk patients. However, due to adverse side effects, transfusion therapy remains a challenge.

Mitochondrial myopathy, encephalopathy, lactic acidosis, and stroke-like episodes (MELAS) is a maternally inherited syndrome caused by mutations in mitochondrial $\mathrm{DNA}^{[3]}$. Studies have shown that the mutational spectrum is broad. About $80 \%$ of MELAS patients exhibit a heteroplasmic mutation in the dihydrouridine loop of the tRNA Leu (UUR) gene at nucleotide position $3243^{[21]}$. Another T-to-C transition at nucleotide position 3271 occurred as a secondary common mutation $^{[3]}$. The pathogenic mtDNA mutations can result in dysfunction of mitochondrial oxidative phosphorylation $(\mathrm{OXPHOS})^{[22]}$, impairing respiratory capacity of the cell and ATP synthesis. Fornuskova et al ${ }^{[22]}$ found that the $3243 \mathrm{~A} \rightarrow \mathrm{G}$ frontal cortex mitochondria showed a marked loss of the complex IV holoenzyme, accompanied by accumulation of assembly intermediates. A similar phenomenon was described in yeast ATP synthase mutants ${ }^{[23]}$. These results disclose new aspects of OXPHOS deficiencies in the brain, particularly in the case of ATP synthase. In addition to diminished energy provisions, an insufficient discharge of mitochondrial membrane potential, leading to reactive oxygen species (ROS) production, was proposed as the underlying pathogenic mechanism of ATP synthase deficiency ${ }^{[24]}$. With regard to mutation screening, urinary sediments, because of a higher proportion of mutant loads, could be an alternative method for the detection of mutant load in MELAS patients ${ }^{[25]}$.

\section{Common multi-factorial stroke Inflammation}

Ischemic brain injury is characterized by acute local inflammation and changes in concentrations of inflammatory cytokines ${ }^{[26]}$, especially in the atherosclerosis subtype.

C-reactive protein (CRP) is an inflammatory molecule that is 
frequently deposited in atherosclerotic lesions in human and animal models ${ }^{[27]}$. In acute-phase reactions, CRP concentrations can increase up to a thousand times, and the association between elevated CRP concentrations and progression of atherosclerosis is well documented ${ }^{[28]}$. Current studies have found the 1059G/C polymorphism in exon 2 of the CRP gene to be an independent genetic risk factor for ischemic stroke ${ }^{[29]}$ and atherosclerosis ${ }^{[30]}$ in older Japanese individuals. However, the association of this variant with cerebrovascular events could not be replicated in younger Chinese subjects ${ }^{[31]}$, which suggests that the effect of the GC genotype might be associated with age. Interestingly, in this study, the CRP 1059G/ C single-nucleotide polymorphism (SNP) was also found to be a genetic determinant for the difference between intra- and extra-cranial cerebral atherosclerosis. Unlike the GG genotype, CRP expression in extra-cranial cerebral arteries is high in individuals with the GC genotype individuals. One possible explanation might be that this variant could influence the endogenous expression of CRP in vessels.

Interleukin-6 (IL-6) is an important mediator of inflammatory events. Elevated plasma levels of IL- 6 are associated with an increased risk and worse outcome of acute vascular events. A common G/C promoter polymorphism in the IL-6 gene has been shown to affect basal IL-6 levels, with the $C$ allele associated with lower plasma IL-6 levels ${ }^{[32]}$. However, epidemiological data on the association of the IL-6 gene polymorphism with ischemic stroke, subtypes and intermediate phenotypes are conflicting. Pola et $a l^{[33]}$ observed an increased risk of ischemic stroke in carriers of the IL-6 GG genotype $(\mathrm{OR}=8.6)$, which is in agreement with the results of Stefan Greisenegger $^{[34]}$. Rundek et al also revealed that the $G$ allele confers an increased risk of $\mathrm{IMT}^{[35]}$. However, several population-based, case-control studies ${ }^{[36]}$ failed to confirm these associations. One study found the CC genotype to be uniquely associated ${ }^{[37]}$ with lacunar stroke, suggesting a particular susceptibility of small, deep penetrators of cerebral arteries to IL-6-mediated inflammatory damage. Further studies are needed to confirm the genotype-phenotype association.

Other inflammatory genes, such as interleukin (IL)-1 $\alpha^{[36]}$, tumor necrosis factor- $\alpha^{[38]}$, IL-10 $0^{[39]}$, intercellular adhesion molecule 1 (ICAM1) ${ }^{[40]}$, and P-selectin ${ }^{[41]}$, have been implicated as susceptibility factors by several independent investigators. However, some studies have not produced positive associations $^{[42]}$.

\section{Hemostatic system}

Genes involved in the hemostatic mechanism are logical candidate genes in prothrombotic conditions of stroke. For example, the mutation of factor V R506Q (FV) makes it resistant to protein $\mathrm{C}^{[43]}$; the gene polymorphisms of prothrombin G20210A is associated with the levels and activity of fibrinogen and prothrombin ${ }^{[44]}$. The gene polymorphisms of platelet surface glycoprotein (GP), such as PlA1/A2 and the Kozak sequence ${ }^{[45]}$, change the structure or function of platelet surface receptors. However, the association between these gene polymorphisms and ischemic stroke are controversial ${ }^{[46,47]}$.
In addition, plasminogen activator inhibitor-1 (PAI-1) plays a key role in fibrinolytic homeostasis. A common single base pair insertion, (5G)/deletion (4G), which occurs 675 bp upstream from the transcription start site of the PAI-1 gene, has been reported to alter levels of plasma PAI-1, with the $4 \mathrm{G}$ allele associated with increased circulating PAI-1 protein levels ${ }^{[48]}$. Considerable data support the view that increased plasma PAI-1 activity is responsible for the decreased fibrinolytic activity in patients with stroke ${ }^{[48]}$. However, epidemiological data on the role of the PAI-1 4G/5G polymorphism in ischemic stroke are still controversial, with some studies ${ }^{[49]}$ finding that $4 \mathrm{G} / 4 \mathrm{G}$ confers an increased risk of stroke and others finding no association ${ }^{[50]}$. Another group demonstrated a protective effect of the $4 \mathrm{G}$ allele against ischemic stroke $(\mathrm{OR}=0.176)$, which may be through a mechanism unrelated to fibrinolysis, and instead involves altered plaque stabilization and/or antagonism of tissue-type plasminogen activator (tPA) effects $^{[51]}$.

\section{Lipid metabolism}

Apolipoprotein E (apo E), a ligand for various cell-surface receptors, modulates the metabolism of atherogenic lipoprotein particles and participates in the process of cellular incorporation of specific lipoproteins. The APOE $\varepsilon 2 / \varepsilon 3 / \varepsilon 4$ polymorphism has been shown to have an impact on total cholesterol, LDL-cholesterol and apoE plasma levels. Total and LDL cholesterol levels were the highest in apoE $\varepsilon 4$ stroke patients and the lowest in $\varepsilon 2$ subjects $^{[52]}$. The role of this polymorphism in ischemic stroke, however, is inconclusive. A study in China showed a 2.1-fold significantly increased risk of ischemic stroke in Apo $\varepsilon 4$ carriers $^{[53]}$. These results were replicated in a Tunisia study ${ }^{[51,54]}$, where Apo $\varepsilon 4$ was found to be higher in the stroke patients $(0.370$ vs $0.181 ; P<0.001)$. Furthermore, there have been reports on the role of the $\varepsilon 4$ allele as a prognostic genetic marker for the atherothrombotic subtype, lacunar infarcts ${ }^{[55]}$ and carotid plaques ${ }^{[56]}$. The $\varepsilon 2$ allele has been reported to be associated with lower risk of carotid atherosclerosis $^{[56]}$ and white matter disease ${ }^{[57]}$. However, several population-based studies ${ }^{[58]}$ have shown no association between Apo $\varepsilon 4 / \varepsilon 2$ and stroke or stroke subtypes. In summary, the findings on the exact role of the Apoc gene in the risk of stroke are not clear.

The paraoxonase (PON) family has been demonstrated to prevent lipid peroxidation and consequently exerts antiatherosclerotic effects. Alteration of enzyme activity due to polymorphisms in the PON genes may influence the development of atheromas and thus affect stroke risk ${ }^{[59]}$. Q192R, a common variant of the PON1 gene, is the major determinant of paraoxonase activity ${ }^{[60]}$. Several studies have shown that rare variants are associated with increased risk of ischemic stroke $^{[61]}$ and IMT $^{[62]}$. However, several researchers ${ }^{[63]}$ failed to replicate these data.

\section{Renin-angiotensin-aldosterone system}

Angiotensin converting enzyme (ACE), an important member of the renin-angiotensin system, is involved in the develop- 
ment of hypertension, atherosclerosis and cardiovascular disease. A deletion (D)/insertion (I) polymorphism of a 287-bp fragment of intron 16 of the ACE gene has been identified as a genetic factor for ischemic stroke ${ }^{[64]}$. Homozygous presence of $\mathrm{D}$ alleles is associated with higher plasma ACE activity. Case-control studies ${ }^{[65,66]}$ revealed that ACE D/D genotypes contribute to ischemic stroke incidence, and this may be due to the effect on essential hypertension. In one study ${ }^{[67]}$, the association between the ACE D allele and lacunar infarction was positive in the normotensive patients, but the association diminished in hypertensive patients, suggesting an independent effect of ACE D alleles on the lacunar infarction. However, regarding the role of ACE polymorphisms in ischemic stroke, the results are uncertain, with several studies failing to confirm the association ${ }^{[68]}$.

Angiotensinogen (AGT), another important member in the renin-angiotensin system, has a methionine to threonine substitution at amino acid 235 (M235T) in which the T allele has been reported to elevate the serum level of AGT, causing an increase in blood pressure ${ }^{[69]}$. As a consequence, van Rijn et $a l^{[69]}$ found an association between the AGT TT genotype and atherosclerosis and white matter lesions (WML). In addition, the AGT 235T allele has been reported to contribute to salt sensitivity ${ }^{[70]}$. However, the effect of the AGT gene polymorphism on the risk of ischemic stroke remains controversial ${ }^{[7]}$.

\section{Hyperhomocysteinemia}

Hyperhomocysteinemia is an independent risk factor for ischemic stroke. A key enzyme, 5,10-methyltetrahydrofolate reductase (MTHFR), is involved in homocysteine metabolism. A common functional polymorphism of MTHFR, C677T, has been found to be associated with differences in homocysteine concentration, with about $1.93 \mu \mathrm{mol} / \mathrm{L}$ between TT and CC homozygotes $^{[72]}$. The MTHFR T allele is thought to be associated with thermolabile MTHFR and reduced enzyme activity. In a meta-analysis ${ }^{[72]}$, the OR for TT homozygotes as an independent risk factor for ischemic stroke was 1.26. Furthermore, the observed increase in risk of stroke among individuals homozygous for the MTHFR T allele was close to that predicted from the differences in homocysteine concentration conferred by this variant. This concordance is consistent with a causal relationship between homocysteine concentration and stroke. In terms of stroke subtypes, the T allele of the MTHFR gene is significantly associated with atherothrombotic stroke and WML in Japanese elderly individuals ${ }^{[73,74]}$. However, some studies have produced controversial results ${ }^{[75]}$. Racialethnic differences in folate metabolism and localized dietary differences may account for the disparity. In addition, there may be an interaction between the HDL-C and MTHFR genotypes in atherothrombotic strokes. The authors believe that Hcy auto-oxidation supports the oxidation of LDL through generation of the superoxide anion radical. Furthermore, it has been reported that VLDL and LDL demonstrate a high binding capacity for Hcy. These findings may indicate synergistic interaction between MTHFR and lipid metabolism in the development of atherothrombotic stroke (Table 1).

\section{Matrix metalloproteinases (MMPs)}

Vascular remodeling is an essential phenomenon in the development of atherosclerotic changes in the arterial wall. MMPs with proteolytic activity against extracellular matrix (ECM) component ${ }^{[76]}$ regulate the accumulation of extracellular matrix during tissue injury, and thus, MMPs regulate the growth of the atherosclerotic plaque ${ }^{[77]}$. Human atheroma samples display increased MMP-3 and MMP-9 expression in plaque shoulder regions and regions of foam cell accumulation $^{[78]}$.

The 5A/6A polymorphism in the MMP-3 promoter region $(-1612)$ is a widely studied gene locus. Most findings support the hypothesis that individuals homozygous for the $6 \mathrm{~A}$ allele have low stromelysin concentrations in their arterial walls due to low gene transcription, and the resulting low proteolytic activity might favor deposition of the extracellular matrix, which would lead to a more rapid development and progression of an atherosclerotic plaque ${ }^{[79]}$. However, other findings do not support this hypothesis ${ }^{[80]}$.

\section{Phosphodiesterase 4D (PDE4D)}

PDE4D, which had previously been identified through GWAs, was identified as the first novel gene to predispose to ischemic stroke independently of conventional risk factors. PDE4D degrades second-messenger $\mathrm{CAMP}^{[81]}$, a key signaling molecule, and leads to increased proliferation and migration of vascular smooth-muscle cells in vitro, which is a hallmark of atherosclerosis ${ }^{[81]}$. In association analyses of an Icelandic population $^{[82]}$, several SNPs in PDE4D were associated with the combined phenotype of cardioembolism (CE) and largeartery atherosclerosis, suggesting a mechanism of accelerated atherosclerosis. Subsequently, Bevan et al ${ }^{[83]}$ performed a study in a non-Icelandic European population and found a possible association with CE stroke, but the lack of an association found with carotid IMT and plaque would suggest a mechanism other than accelerated atherosclerosis. However, the role of PDE4D is inconclusive, with some investigators ${ }^{[84,85]}$ replicating the association and some not ${ }^{[86]}$. Despite extensive genotyping of the PDE4D locus, the disease-causing genetic variant has not been identified thus far.

\section{ALOX5AP and leukotriene pathway}

ALOX5AP encoding 5-lipoxygenase activating protein (FLAP), an important component of the leukotriene pathway, is another gene that has been discovered through GWAs. A haplotype spanning ALOX5AP, HapA, was shown to be associated with a 1.7-fold increased risk of stroke in the Icelandic population ${ }^{[87]}$. The association between HapA and ischemic stroke was subsequently replicated in the Scottish population, which shares a common Gaelic ancestry with the Icelandic population ${ }^{[88]}$. However, negative results have also been demonstrated $^{[84]}$.

Other genetic variations involved in leukotriene biosynthesis, such as the genes encoding LTA4 hydrolase, LTC4 synthase, and the LTB4 receptor, were found to confer an 
Table 1. The association studies between selected candidate genes and ischemic stroke.

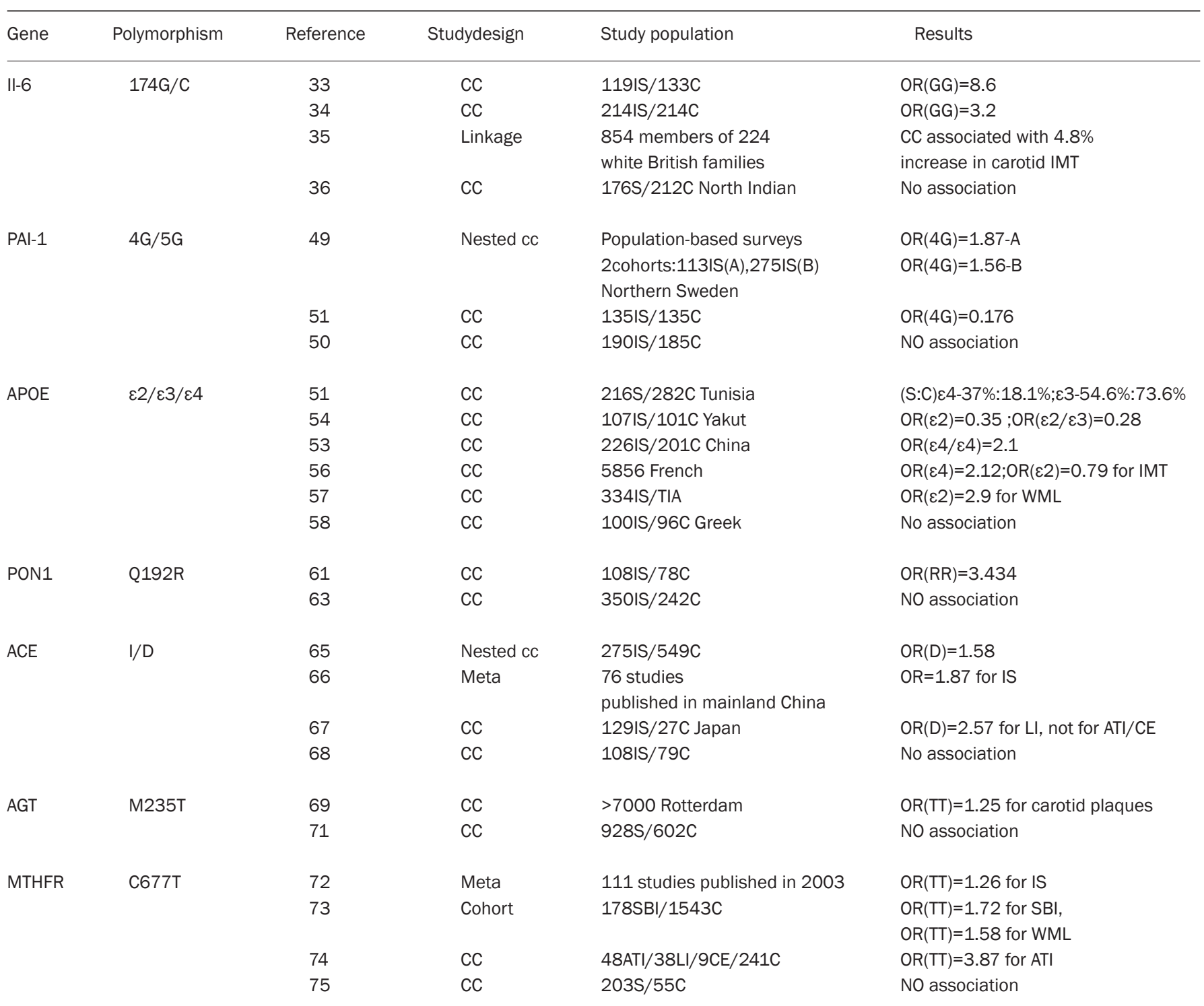

$(\mathrm{CC}=$ case-contol study. $\mathrm{C}=$ controls. $\mathrm{S}=$ stroke. $\mathrm{IS}=$ ischaemic stroke. IMT=intima-media thickness. TIA=transient ischaemic attack. $\mathrm{LI}=\mathrm{lacunar}$ infarction. $\mathrm{ATI}=$ atherothrombotic infarction. $\mathrm{CE}=$ cardiac embolism. $\mathrm{WML}=$ white-matter lesions. $\mathrm{SBI}=$ silent brain infarction. $\mathrm{OR}=\mathrm{odd}$ ratio)

increased risk of ischemic stroke ${ }^{[86,88,89]}$. However, these associations still need to be confirmed by further studies.

\section{Other candidate pathways and genes}

Research on the DNA damage and repair pathway ${ }^{[00]}$, cytochrome $\mathrm{P} 450^{[91]}, \mathrm{COX}-2^{[92]}$, and endothelial nitric oxide synthase $(\mathrm{eNOS})^{[21]}$ in ischemic stroke has been reported; however, there was no reliable evidence of association, and further studies thus are required.

\section{Hemorrhagic stroke}

Hemorrhagic stroke includes two etiologically and pathologically different main disease categories: SAH and ICH. SAH usually results from the rupture of a cerebral arterial aneurysm $^{[93]}$. ICH can be divided into primary ICH (PICH) and secondary ICH. PICH accounts for $78 \%-88 \%$ of ICH cases and is mainly caused by chronic hypertension and spontaneous small vessel rupture due to amyloid angiopathy $(\mathrm{CAA})^{[94]}$.

\section{Single-gene disorder with hemorrhagic stroke}

Two types of hereditary cerebral hemorrhage with amyloidosis (HCHWA) have been described: the Icelandic type (HCHWA-I) and the Dutch type (HCHWA-D). Both are autosomal dominant forms of amyloidosis restricted to the small vasculature of the brain and are clinically characterized by recurrent strokes, leading to an early death. In spite of their clinico-pathological similarities, the amyloid fibrils are structurally different.

HCHWA-D is an autosomal dominant disease caused by a glutamine to glutamic acid substitution at amino acid position 
22 of codon 693 of the amyloid beta precursor protein (A $\beta-P P)$ gene located on chromosome $21^{[95]}$. The main symptoms are (recurrent) hemorrhagic stroke and dementia in the 5th or 6th decade of life ${ }^{[96]}$. About two thirds of patients with HCHWA$D$ experience fatal $\mathrm{ICH}$, and the remaining one third present with vascular dementia. The mutation produces an aberrant $\mathrm{A} \beta$ species (A $\beta$ E22Q) and causes severe meningocortical vascular $A \beta$ deposition ${ }^{[97]}$, which affects the proteolytic degradation of $A \beta$ and its transport across the blood-brain barrier ${ }^{[98]}$. Additionally, emerging studies provide additional evidence for a role of $\mathrm{A} \beta-\mathrm{PP}$ as a modulator of coagulation in in vitro studies. It is hypothesized that local binding of A $\beta$-PP to FXIa and possibly also to factor IXa in cerebral amyloid-loaded vessels may favor the development of $\mathrm{ICH}^{[99]}$.

HCHWA-I, also termed hereditary cystatin C amyloid angiopathy, is an autosomal dominant disorder caused by a mutation in the gene that encodes for the cysteine protease inhibitor, cystatin $\mathrm{C}^{[100]}$. The mutation is a leucine to glutamine amino acid substitution at position 68 (C68Q), which allows the formation of amyloid deposits mainly in the arterial walls in the brain ${ }^{[101]}$. The amino acid substitution promotes an improperly folded, variant cystatin C molecule ${ }^{[102]}$ that is more amyloidogenic. About $17 \%$ of strokes in Icelandic patients younger than 35 years are due to HCHWA-I ${ }^{[99]}$. Most patients with HCHWA-I experience their first stroke before the age of 30 , and most patients die before age 50 .

\section{Common multi-factorial stroke Hemostatic system}

Emerging evidence points to a significant influence of coagulation factor gene polymorphisms on the incidence of hemorrhagic stroke. Among these, the effect of a FXIII Val34Leu polymorphism on ICH has been widely discussed. However, the role of this polymorphism in ICH is still controversial. Previous reports found that the 34Leu allele predisposes individuals to an increased risk for $\mathrm{PICH}$ in an Italian cohort $(\mathrm{OR}=1.70)^{[103]}$. In addition, fibrinogen concentration was found to modify the effect of the polymorphism, such that carriers of the 34Leu allele with a high concentration of fibrinogen may be at risk of hemorrhage ${ }^{[104]}$. Contradictory results, however, have also been reported ${ }^{[47]}$.

\section{Lipid metabolism}

CAA is caused by the accumulation of amyloid beta-protein $(A \beta)$, and the major clinical manifestation of CAA is stroke due to a lobar hemorrhage ${ }^{[94]}$. APOE $\varepsilon 4$ was also found to be associated with CAA. A complex relationship between APOE $\varepsilon 4 / \varepsilon 2$ and hemorrhagic stroke due to CAA (CAAH) is emerging ${ }^{[105]}$. In a study of elderly Japanese individuals ${ }^{[106]}$, APOE $\varepsilon 4$ carriers showed significantly higher CAA severity than non- $\varepsilon 4$ carriers $(p=0.0058)$. Another pathological study has demonstrated that APOE $\varepsilon 2$ is over-represented among patients with $\mathrm{CAAH}^{[107]}$. In addition, the $\varepsilon 2$ allele is specifically associated with CAA-associated microangiopathic changes, such as fibrinoid necrosis and concentric splitting of the vessel wall ${ }^{[107]}$. Generally, it should be noted that the APOE $\varepsilon 4$ allele contributes more to CAA in the elderly, whereas the APOE $\varepsilon 2$ allele contributes more to CAAH.

\section{Alpha-1 antichymotrypsin (ACT)}

$\mathrm{ACT}$, a serine proteinase inhibitor, has been implicated in the pathogenesis of hemorrhagic stroke. The TT genotype of the ACT signal peptide A/T polymorphism has been reported to confer susceptibility to $\mathrm{PICH}^{[108]}$. In analyses restricted to normotensive patients, the association became stronger. The ACT TT genotype may facilitate proteolytic rupture of vessels that harbor amyloidotic changes or play a role in another form of nonhypertensive cerebral angiopathy ${ }^{[108]}$. In a Chinese study, a significant gene-environment interaction, referred to as a super multiplicative type 4 interaction, was shown between both ACT AT and TT genotypes and primary hypertension, which is not fully consistent with other results ${ }^{[109]}$. On the other hand, some results support the data, suggesting a lack of association between the ACT A/T polymorphism and $\mathrm{PICH}^{[110]}$.

\section{Other association studies}

The association between genetic variants of cytokines (IL-6, $\mathrm{TNF})^{[111]}, \mathrm{MMP}-3^{[79]}$ and the ER alpha gene (ESR1) ${ }^{[112]}$ and hemorrhagic stroke has been explored, but the findings are inconclusive $^{[113]}$. In addition, there is mounting evidence ${ }^{[114]}$ that an eNOS T786C SNP predicts susceptibility to post-SAH vasospasm, which is a major cause of morbidity and mortality after SAH.

\section{Animal model}

To claim causality for a genotype-phenotype relationship, the functionality of a candidate variant must be appropriately and convincingly confirmed in vitro and in vivo, the latter usually in animal models.

Spontaneously hypertensive stroke-prone rats (SHR-SP), which are an inbred animal model, resemble stroke in humans in many aspects, such as the dependence on a special permissive dietary regimen (low in potassium and protein, high in sodium) and elevated blood pressure. Conversely, spontaneously hypertensive rats (SHR) remain stroke-free, despite a similar degree of hypertension after exposure to the same diet. The F2 generation from experimental crossbreeding of SHR-SP and SHR can identify genetic loci predisposing specifically to stroke and exclude the confounding factor of blood pressure. The quantitative trait locus, termed Str1/Str2/Str3, identified through a genomic screening approach with quantitative locus mapping in F2 crosses, strongly affected the latency to stroke in SHR-SP fed a stroke-permissive diet ${ }^{[115]}$. Furthermore, Str2 co-localized with the gene for atrial natriuretic peptide (ANP), a hormone with vasoactive properties.

Other animal models of stroke have been generated through genetic engineering. For example, PON1 knockout mice have high amounts of oxidized LDL and are more susceptible to atherosclerosis ${ }^{[116]}$, whereas transgenic mice overexpressing human PON1 have decreased atherosclerotic lesion formation $^{[117]}$. CADASIL knock-in mutant mice have also 
provided valuable information on genetic factors involved in stroke predisposition in human beings.

\section{Potential clinical application of genetics of stroke}

Gene therapy for stroke is one of the most promising frontiers. Theoretically, gene therapy could deliver critical proteins to lesions or bestow on recipient tissue a desired enzymatic or neurotrophic activity to prevent progression and promote regression. In the ApoE mouse, plaque progression was arrested and regression was induced after transfection with the wild-type ApoE gene ${ }^{[118]}$. Significant experimental gene therapy studies have led to currently active clinical trials using direct intracerebral delivery of viral vectors. As with any gene therapeutic strategy, issues about patient selection, route of delivery, vector selection, and appropriate clinical measures attend these nascent efforts ${ }^{[119]}$. However, the translation into clinical application is difficult to realize.

In addition, genetic tests are needed to assess the clinical utility of selecting drugs and doses routinely used to treat patients with stroke or at risk for stroke. For example, genotype-guided warfarin therapy for anticoagulation in elderly patients with AF was reported to be potentially cost-effective, and its benefits were closely related to efficacy in preventing bleeding events ${ }^{[120]}$. However, in general, the clinical usefulness of genetics testing was low, such as the activated protein $\mathrm{C}$ resistance/factor $\mathrm{V}$ Leiden mutation test ${ }^{[121]}$. Many tests were performed based on unsubstantiated or vague indications. Furthermore, normal test results led to unwarranted refraint from giving advice about antithrombotic measures, leading to potential harm to the patient.

\section{Perspectives and limitations}

Since stroke is a complex disease comprising multiple risk factors and multi-gene involvement, unraveling the genetics of stroke represents a unique challenge. Although a large group of candidate genes have been studied, the epidemiological results have varied. The reasons for these contradictory results may be limited sample size, diversity in study design and endpoints, differences in genetic background, and selection of control populations. Thus, greater rigor and consistency in future studies are warranted to elucidate the role of genetic variations in stroke; such work will provide a rationale for preventing strokes with small-molecule therapy and diagnostic tools for predicting risk and the molecular subtype of a past or future stroke $\mathrm{e}^{[122,123]}$.

\section{Acknowledgements}

This work was supported by grants from the National Basic Research Program of China (973 Program, № 2009CB521901) and the National Natural Science Foundation of China (No 30730106, 30901809).

\section{References}

1 World Health Organization. World Health Statistics 2008. World Health Organization, Geneva. 2008.

2 Rosamond W, Flegal K, Furie K, Go A, Greenlund K, Haase N, et al.
Heart disease and stroke statistics: 2008 update. A report from the American Heart Association Statistics Committee and Stroke Statistics Subcommittee. Circulation 2008; 117: E25-46.

3 Dichgans M. Genetics of ischaemic stroke. Lancet Neurol 2007; 6: 149-61.

4 Rosengren A, Hawken S, Ounpuu S, Sliwa K, Zubaid M, Almahmeed WA, et al. Association of psychosocial risk factors with risk of acute myocardial infarction in 11119 cases and 13648 controls from 52 countries (the INTERHEART study): Case control study. Lancet 2004; 364: 953-62.

5 Goldstein LB, Adams R, Alberts MJ, Appel LJ, Brass LM, Bushnell $\mathrm{CD}$, et al. Primary prevention of ischemic stroke: a guideline from the American Heart Association/American Stroke Association Stroke Council. Stroke 2006; 37: 1583-633.

6 Brand-Herrmann SM. Where do we go for atherothrombotic disease genetics? Stroke 2008; 39: 1070-5.

7 Degnan JH, Lasky-Su J, Raby BA, Xu M, Molony C, Schadt EE, et al. Genomics and genome-wide association studies: an integrative approach to expression QTL mapping. Genomics 2008: 92; 129-33.

8 Schulz UG, Flossmann E, Rothwell PM. Heritability of ischemic stroke in relation to age, vascular risk factors, and subtypes of incident stroke in population-based studies. Stroke 2004; 35: 819-24.

9 Jerrard-Dunne P, Cloud G, Hassan A, Markus HS. Evaluating the genetic component of ischemic stroke subtypes: a family history study. Stroke 2003; 34: 1364-69.

10 Au KM, Li HL, Sheng B, Chow TC, Chen ML, Lee KC, et al. A novel mutation $(\mathrm{C} 271 \mathrm{~F})$ in the Notch3 gene in a Chinese man with cerebral autosomal dominant arteriopathy with subcortical infarcts and leukoencephalopathy. Clin Chim Acta 2007; 376: 229-32.

11 Joutel A, Corpechot C, Ducros A, Vahedi K, Chabriat H, Mouton P, et al. NOTCH3 mutations in CADASIL, a hereditary adultonset condition causing stroke and dementia. Nature 1996; 383: 707-10.

12 Artavanis-Tsakonas S, Rand MD, Lake RJ. Notch signaling: cell fate control and signal integration in development. Science 1999; 284: 770-6.

13 Joutel A, Andreux F, Gaulis S, Domenga V, Cecillon M, Battail N, et al. The ectodomain of the Notch3 receptor accumulates within the cerebrovasculature of CADASIL patients. J Clin Invest 2000; 105: 597-605.

14 Lee YC, Yang AH, Liu HC, Wong WJ, Lu YC, Chang MH, et al. Cerebral autosomal dominant arteriopathy with subcortical infarcts and leukoencephalopathy: two novel mutations in the NOTCH3 gene in Chinese. J Neurol Sci 2006; 246: 111-5.

15 Santa Y, Uyama E, Chui DH, Arima M, Kotorii S, Takahashi K, et al. Genetic, clinical and pathological studies of CADASIL in Japan:a partial contribution of Notch3 mutations and implications of smooth muscle cell degeneration for the pathogenesis. J Neurol Sci 2003; 212: $79-84$.

16 Spada M, Pagliardini S, Yasuda M, Tukel T, Thiagarajan G, Sakuraba $\mathrm{H}$, et al. High incidence of later-onset Fabry disease revealed by newborn screening. Am J Hum Genet 2006; 79: 31-40.

17 LucaA De, Bottillo I, Dasdia MC, Morella A, Lanari V, Bernardini L, et al. Deletions of NF1 gene and exons detected by multiplex ligationdependent probe amplification. J Med Genet 2007; 44: 800-8.

18 Driss A, Asare KO, Hibbert JM, Gee BE, Adamkiewicz TV, Stiles JK. Sickle Cell Disease in the Post Genomic Era: a monogenic disease with a polygenic phenotype. Genomics Insights 2009; 2009: 23-48.

19 Sebastiani P, Ramoni MF, Nolan V, Baldwin CT, Steinberg MH. Genetic dissection and prognostic modeling of overt stroke in sickle cell anemia. Nat Genet 2005; 37: 435-40.

20 Nichols FT, Jones AM, Adams RJ. Stroke prevention in sickle cell 
disease (STOP) study guidelines for transcranial Doppler testing. J Neuroimaging 2001; 11: 354-62.

21 Tanji K, Kaufmann P, Naini AB, Lu J, Parsons TC, Wang D, et al. A novel tRNA Val mitochondrial DNA mutation causing MELAS. J Neurol Sci 2008; 270: 23-7.

22 Fornuskova D, Brantova O, Tesarova M, Stiburek L, Honzik T, Wenchich L, et al. The impact of mitochondrial tRNA mutations on the amount of ATP synthase differs in the brain compared to other tissues. Biochim Biophys Acta 2008; 1782: 317-25.

23 Rak M, Tetaud E, Godard F, Sagot I, Salin B, Duvezin-Caubet S, et al. Yeast cells lacking the mitochondrial gene encoding the ATP synthase subunit 6 exhibit a selective loss of complex IV and unusual mitochondrial morphology. J Biol Chem 2007; 282: 10853-64.

24 Houstek J, Mracek T, Vojtiskova A, Zeman J. Mitochondrial diseases and ATPase defects of nuclear origin. Biochim Biophys Acta 2004; 1658: 115-21.

25 Chou HF, Liang WC, Zhang Q, Goto Y, Jong YJ. Clinical and genetic features in a MELAS child with a $3271 T>C$ mutation. Pediatr Neurol 2008; 38: 143-6.

26 Liu AJ, Guo JM, Xia W, Su DF. New strategies for the prevention of stroke. Clin Exp Pharmacol Physiol 2010; 37: 265-71.

27 Krupinski J, Turu MM, Martinez-Gonzalez J, Carvajal A, Juan-Babot $\mathrm{JO}$, Iborra $\mathrm{E}$, et al. Endogenous expression of C-reactive protein is increased in active (ulcerated noncomplicated) human carotid artery plaques. Stroke 2006; 37: 1200-4.

28 Ridker PM, Silvertown JD. Inflammation, C-reactive protein, and atherothrombosis. J Periodontol 2008; 79: 1544-51.

29 Morita A, Nakayama T, Soma M. Association study between C-reactive protein genes and ischemic stroke in Japanese subjects. Am J Hypertens 2006; 19: 593-600.

30 Morita A, Nakayama T, Doba N, Hinohara S, Soma M. Polymorphism of the C-reactive protein (CRP) gene is related to serum CRP concentration and arterial pulse wave velocity in healthy elderly Japanese. Hypertens Res 2006; 29: 323-31.

31 Liu ZZ, Lv H, Gao F, Liu G, Zheng HG , Zhou YL, et al. Polymorphism in the human $\mathrm{C}$-reactive protein (CRP) gene, serum concentrations of CRP, and the difference between intracranial and extracranial atherosclerosis. Clin Chim Acta 2008; 389: 40-4.

32 Tso AR, Merino JG, Warach S. Interleukin-6 174G/C polymorphism and ischemic stroke: a systematic review. Stroke 2007; 38: 3070-5.

33 Pola R, Flex A, Gaetani E, Flore R, Serricchio M, Pola P. Synergistic effect of $174 \mathrm{G} / \mathrm{C}$ polymorphism of the interleukin- 6 gene promoter and $469 \mathrm{E} / \mathrm{K}$ polymorphism of the intercellular adhesion molecule-1 gene in Italian patients with history of ischemic stroke. Stroke 2003; 34: 881-5.

34 Greisenegger S, Endler G, Haering D, Schillinger M, Lang W, Lalouschek W, et al. The (174) G/C polymorphism in the interleukin-6 gene is associated with the severity of acute cerebrovascular events. Thromb Res 2003; 110: 181-6.

35 Rundek T, Elkind MS, Pittman J, Boden-Albala B, Martin S, Humphries $\mathrm{SE}$, et al. Carotid intima-media thickness is associated with allelic variants of stromelysin-1, interleukin-6, and hepatic lipase genes: the Northern Manhattan Prospective Cohort Study. Stroke 2002; 33 : 1420-3

36 Banerjee I, Gupta V, Ahmed T, Faizaan M, Puneet A, Ganesh S. Inflammatory system gene polymorphism and the risk of stroke: A case-control study in an Indian population. Brain Res Bull 2008; 75 : 158-65.

37 Chamorro A, Revilla M, Obach V, Vargas M, Planas AM. The -174G/ $C$ polymorphism of the interleukin 6 gene is a hallmark of lacunar stroke and not other ischemic stroke phenotypes. Cerebrovasc Dis
2005; 19: 91-5.

38 Pereira TV, Rudnicki M, Franco RF, Pereira AC, Krieger JE. Effect of the G-308A polymorphism of the tumor necrosis factor alpha gene on the risk of ischemic heart disease and ischemic stroke: a metaanalysis. Am Heart J 2007; 153: 821-30.

39 Trompet S, Pons D, DE Craen AJ, Slagboom P, Shepherd J, Blauw GJ, et al. Genetic variation in the interleukin-10 gene promoter and risk of coronary and cerebrovascular events: the PROSPER study. Ann N Y Acad Sci 2007; 1100: 189-98.

40 Zee RY, Cheng S, Erlich HA, Lindpaintner K, Rifai N, Buring JE, et al. Intercellular adhesion molecule 1 (ICAM1) Lys56Met and Gly241Arg gene variants, plasma-soluble ICAM1 concentrations, and risk of incident cardiovascular events in 23,014 initially healthy white women. Stroke 2007; 38: 3152-7.

41 Volcik KA, Ballantyne CM, Coresh J, Folsom AR, Boerwinkle E. Specific P-selectin and P-selectin glycoprotein ligand-1 genotypes/ haplotypes are associated with risk of incident $\mathrm{CHD}$ and ischemic stroke: the Atherosclerosis Risk in Communities (ARIC) study. Atherosclerosis 2007; 195: e76-82.

42 Bis JC, Heckbert SR, Smith NL, Reiner AP, Rice K, Lumley T, et al. Variation in inflammation-related genes and risk of incident nonfatal myocardial infarction or ischemic stroke. Atherosclerosis 2008; 198: 166-73.

43 Bertina RM, Koeleman BP, Koster T, Rosendaal FR, Dirven RJ, de Ronde $\mathrm{H}$, et al. Mutation in blood coagulation factor $\mathrm{V}$ associated with resistance to activated protein C. Nature 1994; 369: 64-7

44 Carty CL, Cushman M, Jones D, Lange LA, Hindorff LA, Rice K, et al. Associations between common fibrinogen gene polymorphisms and cardiovascular disease in older adults. Thromb Haemost 2008; 99 : 388-95.

45 Maguire JM, Thakkinstian A, Sturm J, Levi C, Lincz L, Parsons M, et al. Polymorphisms in platelet glycoprotein 1 balpha and factor VII and risk of ischemic stroke: a meta-analysis. Stroke 2008; 39: 1710-6.

46 Slowik A, Dziedzic T, Pera J, Figlewicz DA, Szczudlik A. Coagulation factor XIII Val34Leu polymorphism in patients with small vessel disease or primary intracerebral hemorrhage. Cerebrovasc Dis 2005; 19: 165-70.

47 Smith NL, Bis JC, Biagiotti S, Rice K, Lumley T, Kooperberg C, et al. Variation in 24 hemostatic genes and associations with non-fatal myocardial infarction and ischemic stroke. J Thromb Haemost 2008; 6: $45-53$.

48 Chen $\mathrm{CH}$, Eng HL, Chang CJ, Tsai TT, Lai ML, Chen HY, et al. 4G/5G promoter polymorphism of plasminogen activator inhibitor-1, lipid profiles, and ischemic stroke. J Lab Clin Med 2003; 142: 100-5.

49 Wiklund P-G, Nilsson L, Ardnor SN, Eriksson P, Johansson L, Stegmayr $B$, et al. Plasminogen activator inhibitor-1 $4 G / 5 G$ polymorphism and risk of stroke: Replicated findings in two nested case-control studies based on independent cohorts. Stroke 2005; 36: 1661-5.

50 Attia J, Thakkinstian A, Wang Y, Lincz L, Parsons M, Sturm J, et al. The PAI-1 4G/5G gene polymorphism and ischemic stroke: an association study and meta-analysis. J Stroke Cerebrovasc Dis 2007; 16: 173-9.

51 Saidi S, Slamia LB, Mahjoub T, Ammou SB, Almawi WY. Association of PAl-1 4G/5G and -844G/A gene polymorphism and changes in PAl-1/tPA levels in stroke: a case-control study. J Stroke Cerebrovasc Dis 2007 ; 16: 153-9.

52 Tasdemir N, Tamam Y, Toprak R, Tamam B, Tasdemir MS. Association of apolipoprotein $\mathrm{E}$ genotype and cerebrovascular disease risk factors in a Turkish population. Int J Neurosci 2008; 118: 1109-29.

53 Jin ZQ, Fan YS, Ding J, Chen M, Fan W, Zhang GJ, et al. Association of apolipoprotein $\mathrm{E} 4$ polymorphism with cerebral infarction in Chinese 
Han population. Acta Pharmacol Sin 2004; 25: 352-6.

54 Parfenov MG, Nikolaeva TY, Sudomoina MA, Fedorova SA, Guekht $A B$, Gusev El, et al. Polymorphism of apolipoprotein E (APOE) and lipoprotein lipase (LPL) genes and ischaemic stroke in individuals of Yakut ethnicity. J Neurol Sci 2007; 255: 42-9.

55 Lai CL, Liu CK, Lin RT, Tai CT. Association of apolipoprotein E polymorphism with ischemic stroke subtypes in Taiwan. Kaohsiung J Med Sci 2007; 23: 491-7.

56 Debette S, Lambert JC, Gariépy J, Fievet N, Tzourio C, Dartigues JF, et al. New insight into the association of apolipoprotein $E$ genetic variants with carotid plaques and intima-media thickness. Stroke 2006; 37: 2917-23.

57 Lemmens R, Görner A, Schrooten M, Thijs V. Association of apolipoprotein $\mathrm{E}$ epsilon2 with white matter disease but not with microbleeds. Stroke 2007; 38: 1185-8.

58 Giassakis G, Veletza S, Papanas N, Heliopoulos I, Piperidou H. Apolipoprotein E and first-ever ischaemic stroke in Greek hospitalized patients. J Int Med Res 2007; 35: 127-33.

59 Kim NS, Kang K, Cha MH, Kang BJ, Moon J, Kang BK, et al. Decreased paraoxonase-1 activity is a risk factor for ischemic stroke in Koreans. Biochem Biophys Res Commun 2007; 364: 157-62.

60 Bhattacharyya T, Nicholls SJ, Topol EJ, Zhang R, Yang X, Schmitt D, et al. Relationship of paraoxonase 1 (PON1) gene polymorphisms and functional activity with systemic oxidative stress and cardiovascular risk. JAMA 2008; 299: 1265-76.

61 Can Demirdöğen B, Türkanoğlu A, Bek S, Sanisoğlu Y, Demirkaya S, Vural O, et al. Paraoxonase/ arylesterase ratio, PON1 192Q/R polymorphism and PON1 status are associated with increased risk of ischemic stroke. Clin Biochem 2008; 41: 1-9.

62 Fortunato G, Rubba P, Panico S, Trono D, Tinto N, Mazzaccara C, et al. A paraoxonase gene polymorphism, PON 1 (55), as an independent risk factor for increased carotid intimamedia thickness in middle-aged women. Atherosclerosis 2003; 167: 141-8.

63 Shin BS, Oh SY, Kim YS, Kim KW. The paraoxonase gene polymorphism in stroke patients and lipid profile. Acta Neurol Scand 2008; 117: $237-43$.

64 Zintzaras E, Raman G, Kitsios G, Lau J. Angiotensin-converting enzyme insertion/deletion gene polymorphic variant as a marker of coronary artery disease: a meta-analysis. Arch Intern Med 2008; 168: 1077-89.

65 Möllsten A, Stegmayr B, Wiklund PG. Genetic polymorphisms in the renin-angiotensin system confer increased risk of stroke independently of blood pressure: a nested case-control study. J Hypertens 2008; 26: 1367-72.

66 Xu X, Li J, Sheng W, Liu L. Meta-analysis of genetic studies from journals published in China of ischemic stroke in the Han Chinese population. Cerebrovasc Dis 2008; 26: 48-62.

67 Mizuno T, Makino M, Fujiwara Y, Nagura J, Shiga K, Yoshikawa K, et al. Renin-angiotensin system gene polymorphism in Japanese stroke patients. Int Congress Series 2003; 1252: 83-90.

68 Tuncer N, Tuglular S, Kiliç G, Sazci A, Us O, Kara I. Evaluation of the angiotensin-converting enzyme insertion/deletion polymorphism and the risk of ischemic stroke. J Clin Neurosci 2006; 13: 224-7.

69 Van Rijn MJ, Bos MJ, Isaacs A, Yazdanpanah M, Arias-Vásquez A, Stricker $\mathrm{BH}$, et al. Polymorphisms of the renin-angiotensin system are associated with blood pressure, atherosclerosis and cerebral white matter pathology. J Neurol Neurosur Ps 2007; 78: 1083-7.

70 Katsuya T, Ishikawa K, Sugimoto K, Rakugi H, Ogihara T. Salt sensitivity of Japanese from the viewpoint of gene polymorphism. Hypertens Res 2003; 26: 521-5.

71 Kostulas K, Brophy VH, Moraitis K, Manolescu A, Kostulas V,
Gretarsdottir S, et al. Genetic profile of ischemic cerebrovascular disease and carotid stenosis. Acta Neurol Scand 2008; 7: 146-52

72 Casas JP, Bautista LE, Smeeth L, Sharma P, Hingorani AD. Homocysteine and stroke: evidence on a causal link from mendelian randomization. Lancet 2005; 365: 224-32.

73 Kohara K, Fujisawa M, Ando F, Tabara Y, Niino N, Miki T, et al. MTHFR gene polymorphism as a risk factor for silent brain infarcts and white matter lesions in the Japanese general population: The NILS-LSA Study. Stroke 2003; 34 : 1130-5.

74 Kawamoto R, Kohara K, Oka Y, Tomita H, Tabara Y, Miki T. An association of 5,10-methylenetetrahydrofolate reductase (MTHFR) gene polymorphism and ischemic stroke. J Stroke Cerebrovasc Dis 2005; 14: 67-74.

75 Dikmen M, Ozbabalik D, Gunes HV, Degirmenci I, Bal C, Ozdemir G, et al. Acute stroke in relation to homocysteine and methylenetetrahydrofolate reductase gene polymorphisms. Acta Neurol Scand 2006; 113 : 307-14.

76 Fornage M, Mosley TH, Jack CR, de Andrade M, Kardia SL, Boerwinkle $\mathrm{E}$, et al. Family-based association study of matrix metalloproteinase-3 and -9 haplotypes with susceptibility to ischemic white matter injury. Hum Genet 2007; 120: 671-80.

77 Humphries SE, Morgan L. Genetic risk factors for stroke and carotid atherosclerosis: insights into pathophysiology from candidate gene approaches. Lancet Neurol 2004; 3: 227-36.

78 Galis ZS, Sukhova GK, Lark MW, Libby P. Increased expression of matrix metalloproteinases and matrix degrading activity in vulnerable regions of human atherosclerotic plaques. J Clin Invest 1994; 94: 2493-503.

79 Kaplan RC, Smith NL, Zucker S, Heckbert SR, Rice K, Psaty BM. Matrix metalloproteinase-3 (MMP3) and MMP9 genes and risk of myocardial infarction, ischemic stroke, and hemorrhagic stroke. Atherosclerosis 2008; 201: 130-7.

80 Armstrong C, Abilleira S, Sitzer M, Markus HS, Bevan S. Polymorphisms in MMP family and TIMP genes and carotid artery intimamedia thickness. Stroke 2007; 38: 2895-9.

81 Houslay MD, Adams DR. PDE4 cAMP phosphodiesterases: modular enzymes that orchestrate signalling cross-talk, desensitization and compartmentalization. Biochem J 2003; 370: 1-18.

82 Gretarsdottir S, Thorleifsson G, Reynisdottir ST, Manolescu A, Jonsdottir S, Jonsdottir T, et al. The gene encoding phosphodiesterase 4D confers risk of ischemic stroke. Nat Genet 2003; 35: 131-8.

83 Bevan S, Porteous L, Sitzer M, Markus HS. Phosphodiesterase 4D gene, ischemic stroke, and asymptomatic carotid atherosclerosis. Stroke 2005; 36: 949-53.

84 Kostulas K, Gretarsdottir S, Kostulas V, Manolescu A, Helgadottir A, Thorleifsson G, et al. PDE4D and ALOX5AP genetic variants and risk for ischemic cerebrovascular disease in Sweden. J Neurol Sci 2007; 263: 113-7.

85 Xue $\mathrm{H}$, Wang $\mathrm{H}$, Song X, Li W, Sun K, Zhang W, et al. Phosphodiesterase $4 D$ gene polymorphism is associated with ischemic and hemorrhagic stroke. Clin Sci (Lond) 2009; 116: 335-40.

86 Bevan S, Dichgans M, Wiechmann HE, Gschwendtner A, Meitinger $\mathrm{T}$, Markus HS. Genetic variation in members of the leukotriene biosynthesis pathway confer an increased risk of ischemic stroke: a replication study in two independent populations. Stroke 2008; 39 : 1109-14.

87 Helgadottir A, Manolescu A, Thorleifsson G, Gretarsdottir S, Jonsdottir $\mathrm{H}$, Thorsteinsdottir $\mathrm{U}$, et al. The gene encoding 5-lipoxygenase activating protein confers risk of myocardial infarction and stroke. Nat Genet 2004; 36: 233-9.

88 Freiberg JJ, Tybjaerg-Hansen A, Sillesen H, Jensen GB, Nordestgaard 
BG. Promotor polymorphisms in leukotriene C4 synthase and risk of ischemic cerebrovascular disease. Arterioscler Thromb Vasc Biol 2008; 28: 990-6.

89 Wang X, Cheng S, Brophy VH, Erlich HA, Mannhalter C, Berger K, et al. A meta-analysis of candidate gene polymorphisms and ischemic stroke in 6 study populations: association of lymphotoxin-alpha in nonhypertensive patients. Stroke 2009; 40: 683-95.

90 Mahabir S, Abnet CC, Qiao YL, Ratnasinghe LD, Dawsey SM, Dong ZW, et al. A prospective study of polymorphisms of DNA repair genes XRCC1, XPD23 and APE/ref-1 and risk of stroke in Linxian, China. J Epidemiol Community Health 2007; 61: 737-41.

91 Marciante KD, Totah RA, Heckbert SR, Smith NL, Lemaitre RN, Lumley $\mathrm{T}$, et al. Common variation in cytochrome P450 epoxygenase genes and the risk of incident nonfatal myocardial infarction and ischemic stroke. Pharmacogenet Genomics 2008; 18: 535-43.

92 Maguire J, Thakkinstian A, Levi C, Lincz L, Bisset L, Sturm J, et al. Impact of COX-2 rs5275 and rs20417 and GPIIla rs5918 Polymorphisms on 90-Day Ischemic Stroke Functional Outcome: A Novel Finding. J Stroke Cerebrovasc Dis 2010. doi: 10.1016/j.jstrokecereb rovasdis.2009.10.011

93 Zhang B, Fugleholm K, Day LB, Ye Shu, Weller R, Day lan NM, et al. Molecular pathogenesis of subarachnoid haemorrhage. Int $J$ Biochem Cell Biol 2003; 35: 1341-60.

94 Vernooij MW, van der Lugt A, Ikram MA, Wielopolski PA, Niessen WJ, Hofman A, Krestin GP, et al. Prevalence and risk factors of cerebral microbleeds: the Rotterdam Scan Study. Neurology 2008; 70 : 1208-14.

95 Levy E, Carman MD, Fernandez- Madrid Y, Power MD, Lieberburg I, Van Duinen SG, et al. Mutation of the Alzheimer's disease amyloid gene in hereditary cerebral hemorrhage-Dutch type. Science 1990; 248: 1124-6.

96 Bornebroek M, Haan J, Maat-Schieman MLC, Van Duinen SG, Roos RAC. Hereditary cerebral hemorrhage with amyloidosis-Dutch type (HCHWA-D): I - a review of the clinical, radiologic and genetic aspects. Brain Pathol 1996; 6: 111-4.

97 Nishitsuji K, Tomiyama T, Ishibashi K, Kametani F, Ozawa K, Okada $\mathrm{R}$, et al. Cerebral vascular accumulation of Dutch-type Abeta42, but not wild-type Abeta42, in hereditary cerebral hemorrhage with amyloidosis, Dutch type. J Neurosci Res 2007; 85: 2917-23.

98 Maat-Schieman M, Roos R, van Duinen S. Hereditary cerebral hemorrhage with amyloidosis-Dutch type. Neuropathology 2005; 25 : 288-97.

99 Meschia JF, Brott TG, Brown RD. Genetics of cerebrovascular disorders. Mayo Clin Proc 2005; 80: 122-32.

100 Revesz T, Holton JL, Lashley T, Plant G, Rostagno A, Ghiso J, et al. Sporadic and familial cerebral amyloid angiopathies. Brain Pathol 2002; 12: 343-57.

101 Wei LH, Walker LC, Levy E. Cystatin C. Icelandic-like mutation in an animal model of cerebrovascular beta-amyloidosis. Stroke 1996; 27 : 2080-5.

102 Calero M, Pawlik M, Soto C, Castaño EM, Sigurdsson EM, Kumar $A$, et al. Distinct properties of wild-type and the amyloidogenic human cystatin $\mathrm{C}$ variant of hereditary cerebral hemorrhage with amyloidosis, Icelandic type. J Neurochem 2001; 77: 628-37.

103 Gemmati D, Serino ML, Ongaro A, Tognazzo S, Moratelli S, Resca $\mathrm{R}$, et al. A common mutation in the gene for coagulation factor XII$A($ Val 34Leu):A risk factor for primary intracerebral hemorrhage is protective against atherothrombotic diseases. Am J Hematol 2001; 67: 183-8.

104 Lim BCB, Ariens RAS, Carter AM, Wesel JM, Grant PJ. Genetic regulation of fibrin structure and function:complex gene-environment interactions may modulate vascular risk. Lancet 2003; 361: 1424-31.
105 Tzourio C, Arima H, Harrap S, Anderson C, Godin O, Woodward M, et al. APOE genotype, ethnicity, and the risk of cerebral hemorrhage. Neurology 2008; 70: 1322-8.

106 Yamada M, Sodeyama N, Itoh Y, Takahashi A, Otomo E, Matsushita M, et al. Association of neprilysin polymorphism with cerebral amyloid angiopathy. J Neurol Neurosurg Psychiatry 2003; 74: 749-51.

107 Yamada M. Cerebral amyloid angiopathy and gene polymorphisms. J Neurol Sci 2004; 226: 41-4.

108 Obach V, Revilla M, Vila N, Cervera AA, Chamorro AA. alpha(1)antichymotrypsin polymorphism: a risk factor for hemorrhagic stroke in normotensive subjects. Stroke 2001; 32: 2588-91.

109 Fu Y, Xie R, Wang Y, Chen D, Zhang Y, Wang G, et al. Association between alpha-1-antichymotrypsin gene polymorphism and cerebral hemorrhage. Zhonghua Yi Xue Za Zhi 2002; 82: 915-7. Chinese.

110 Dardiotis E, Hadjigeorgiou GM, Dardioti M, Scarmeas N, Paterakis K, Aggelakis $\mathrm{K}$, et al. Alpha- 1 antichymotrypsin gene signal peptide $\mathrm{a} / \mathrm{t}$ polymorphism and primary intracerebral hemorrhage. Eur Neurol 2008; 59: 307-14.

111 Fontanella M, Rainero I, Gallone S, Rubino E, Fenoglio P, Valfrè W, et al. Interleukin 6 gene polymorphisms are not associated with aneurysmal subarachnoid haemorrhage in an Italian population. J Neurol Neurosurg Psychiatry 2008; 79: 471-3.

112 Strand M, Söderström I, Wiklund PG, Hallmans G, Weinehall L, Söderberg S, et al. Estrogen receptor alpha gene polymorphisms and first-ever intracerebral hemorrhage. Cerebrovasc Dis 2007; 24: 500-8.

113 Bos MJ, Schuit SC, Koudstaal PJ, Hofman A, Uitterlinden AG, Breteler MM. Variation in the estrogen receptor alpha gene and risk of stroke: the Rotterdam Study. Stroke 2008; 39: 1324-6.

114 Ko NU, Rajendran P, Kim H, Rutkowski M, Pawlikowska L, Kwok PY, et al. Endothelial nitric oxide synthase polymorphism (-786T->C) and increased risk of angiographic vasospasm after aneurysmal subarachnoid hemorrhage. Stroke 2008; 39: 1103-8.

115 Rubattu S, Volpe M, Kreutz R, Ganten U, Ganten D, Lindpaintner K. Chromosomal mapping of quantitative trait loci contributing to stroke in a rat model of complex human disease. Nat Genet 1996; 13: 429-34.

116 Shih DM, Gu L, Xia YR, Navab M, Li WF, Hama S, et al. Mice lacking serum paraoxonase are susceptible to organophosphate toxicity and atherosclerosis. Nature 1998; 394: 284-7.

117 Tward A, Xia YR, Wang X, Shi YS, Park C, Castellani LW, et al. D alcreased atherosclerotic lesion formation in human serum paraoxonase transgenic mice. Circulation 2002; 106: 484-90.

118 Rouis M, Adamy C, Duverger N, Lesnik P, Horellou P, Moreau M, et al. Adenovirus-mediated overexpression of tissue inhibitor of metalloproteinase-1 reduces atherosclerotic lesions in apolipoprotein E-deficient mice. Circulation 1999; 100: 533-40.

119 Worrall BB, Degraba TJ. The genetics of cerebrovascular atherosclerosis. J Stroke Cerebrovasc Dis 2002; 11: 220-9.

120 Leey JA, McCabe S, Koch JA, Miles TP. Cost-effectiveness of genotype-guided warfarin therapy for anticoagulation in elderly patients with atrial fibrillation. Am J Geriatr Pharmacother 2009; 7: 197-203.

121 Blinkenberg EO, Kristoffersen AH, Sandberg S, Steen VM, Houge G. Usefulness of factor $V$ Leiden mutation testing in clinical practice. Eur J Hum Genet 2010; 18: 862-6.

122 Dindagur N, Kruthika-Vinod T.P, Christopher R. Thrombophilic gene polymorphisms in puerperal cerebral veno-sinus thrombosis. J Neurol Sci 2006; 249: 25-30.

123 Pruissen DM, Slooter AJ, Rosendaal FR, van der Graaf Y, Algra A. Coagulation factor XIII gene variation, oral contraceptives, and risk of ischemic stroke. Blood 2008; 111: 1282-6. 